\title{
A Study on the Way in which Words Are Organized in Iranian EFL Learners' Mental Lexicon
}

\author{
Sedigheh Sharifi ${ }^{1}$, Masoud Khalili Sabet ${ }^{2}$, Abdorreza Tahriri ${ }^{2}$ \\ ${ }^{1}$ English Department, the University of Guilan, Rasht, Guilan, Iran \\ ${ }^{2}$ Faculty member at the University of Guilan, Rasht, Guilan, Iran
}

Corresponding Author: Sedigheh Sharifi, E-mail: sedighehsharifi19@gmail.com

\begin{tabular}{l} 
ARTICLE INFO \\
\hline Article history \\
Received: April 22, 2018 \\
Accepted: July 29, 2018 \\
Published: November 01, 2018 \\
Volume: 7 Issue: 6 \\
Advance access: September 2018
\end{tabular}

Conflicts of interest: None Funding: None

\begin{abstract}
Vocabulary learning in both L1 and L2 is considered important to master a language. Individuals need to learn the words in order to express ideas and to communicate. As a result, research into word knowledge is important as it provides useful information considering the way in which words are learned and organized in individuals' mind; however different studies have been conducted in this regard, there is a long way to fully understand individuals' mental lexicon. So, word association tests are used to examine the word knowledge, to study vocabulary learning process, and how it occurs in the language learners' mind. Similarly, the aim of this paper is to investigate the way in which words are stored and organized in Iranian EFL learners' mental lexicon through a word association test. To this end, a word association test was designed including eight prompt words from different word classes and was administered to 50 Iranian EFL learners. They were randomly selected and included 22 males and 28 females from Razi University and an institute in Kermanshah, Iran. After administering the test, to analyze the data, learners' responses were classified and the frequency of each classification of word association was calculated and chi-square tests were run to compare responses. Results reveal that the participants displayed different patterns in their responses as syntagmatic and paradigmatic classification. Most of them made more syntagmatic responses than paradigmatic ones. As a result, it can be concluded that more participants make mental links with syntagmatic compared to others who make links with paradigmatic and there are significant differences between male and female learners in the use of syntagmatic and paradigmatic responses; on the other hand, it appears that there is no significant differences in learners' word association regarding age. This study has useful implications for both EFL teachers and learners by helping them understand and improve the lexical acquisition process.
\end{abstract}

Key words: Word Association, Mental Lexicon, Syntagmatic and Paradigmatic Links

\section{INTRODUCTION}

The present study is going to provide precise insight into the way in which words are learned, organized, and linked in the EFL learners' mind by using a perfect word association test. Therefore, this paper will uncover the organization and development of words in learners' mental lexicon.

The process of foreign language learning refers to the learning a nonnative language that is not the language of communication of the environment in which the language is learned (Moeller \& Catalano, 2015). Primarily, vocabulary is regarded as a basic aspect in language learning process. That is why vocabulary is now occupied a center stage in all language learning programs. So, it is understood that vocabulary knowledge is very essential for learners' academic attainments. (Udaya, 2015, p.43)

Nation (1990) lists a number of various types of word knowledge that every single individual requires to have so that (s) he knows a word, such knowledge as pronunciation, spelling, grammatical class, collocation, register, frequency, and association of word. These are referred to as kinds of word knowledge, and they are required to make possible to know a word and to use it in different language situations individuals put in. (cited in Schmitt, 2000).

Every knowledge regarding vocabulary has a well organization in one's mind such as the way in which words are stored and interrelated to one another in the mental lexicon (Fidayanti, 2013). Schmitt (2014) believes that:

"The mental lexicon is a complex phenomenon, and the exact nature of lexical knowledge has always perplexed researchers and teachers. This is not surprising as a lexicon can hold many thousands of words, each with numerous links of various kinds to the other words in the lexical network. Moreover, the links between different words are often difficult to explain clearly, thus making research into these links difficult. Descriptions of the mental lexicon are further complicated by the fact that each word does not usually exist on 
its own, but rather is typically a part of a word family with numerous related members (e.g., joy, joyful, joyous, joyfully), of a lexical set (emotion, joy, ecstasy).” (pp. 913-914)

A large number of researchers have recently focused on the mental lexicon and many books have been published on it. The phenomenon of storing words in human's mind is often called the "mental dictionary" or, it is probably more common to be known as the "mental lexicon" which is Greek word for dictionary. But there are differences between the organization of vocabulary in mind and the organization of vocabulary in dictionary, although the information will sometimes be similar. The dissimilarities are related to both organization and content. For example, regarding organization, words are standardly presented in alphabetical order in dictionaries. Some people might also feel that a literate person would similarly organize the lexical items in the mind. This hypothesis is easy to test. People usually make mistakes while speaking; they select, as an example, one word for another incorrectly. If the lexical items are alphabetically organized in the mind, it may be expected that speakers accidentally pick an adjacent entry when this error occurs (Aitchison, 2012).

\section{Statement of the Problem}

Vocabulary has been taken into consideration as an important part of language in foreign language learning process. Researchers have been carrying out different studies over the recent decades and they have provided a series of facts and details to facilitate the process of learning. Learning the way in which words are connected is considered as a significant way to learn vocabulary in foreign language learning. On the other hand, this type of word knowledge has been ignored by Iranian EFL learners. This study is going to help both EFL teachers and learners pay more attention to word association.

\section{Research Questions}

1. Which kind of links is used more frequently: meaning-based or form-based?

3. Are there differences in learners' word association in terms of age and gender?

\section{LITERATURE REVIEW}

\section{Word Association}

In the past few decades, the effect of vocabulary in English language teaching and learning processes has been receiving a large amount of attention and often has been the focus of discussions. Also "Understanding relations between words means having a rich and a densely interconnected mental lexicon, which is considered an important feature of developing language proficiency" (Cremer, Dingshoff, Beer and Schoonen, 2010). Word association is generally defined as the mental connections made between words and it describes those connections (Brown, 2006). And the mental lexicon is "a person's mental store of words, their meaning and associ- ations". (Richards and Schmidt, 2002, p.327)

So, Richards et al (cited in Brown, 2006) describe this type of word knowledge -word association- as links and connections made between vocabularies in the mental lexicon which affect the process of lexical acquisition.

\section{Word Association Classifications}

Generally, Thomas (2006) -in his study- determined the following classes of association:

Semantic, formal, and other associations. Semantic associations refer to associations that contrary to form based associations are semantically related. These associations themselves are of syntagmatic and paradigmatic, syntagmatic ones include associations which have a different grammatical function than the prompt and the learner could easily find out its connection with the prompt word. They include words of the same class that exhibit a very strong collocational connection to the prompt word (ex. good + boy and book + store) as well. On the other hand, paradigmatic association consists of associations that are of the same grammatical function as the prompt word and they are not collocationally related to one another. Subclasses of paradigmatic connection made between words in the mental lexicon are:

- $\quad$ Synonymy ( $x$ has the same meaning as $y$ )

- Antonymy (x has the opposite meaning of $y$ )

- Hyponymy ( $\mathrm{x}$ is considered as a type of $\mathrm{y}$; known as "subordination" too)

- Co-hyponymy (x and y both are regarded as types of $\mathrm{z}$; known as "co-cordination" too)

- Hypernymy (x possesses y as one of its types; known as "superordination" too)

- Meronymy ( $\mathrm{x}$ is considered as a part of $\mathrm{y}$; known as "partonymy" too)

Another class of association proposed by Thomas is formal in which associations are form based not meaning based. These contain phonological and orthographic associations. Phonological that usually known as "clang" associations involve responses phonologically related. This contains such things as rhyme and the "bathtub effect". For example float - boat, flu - blue, train - brain. These examples often have a rhyming or near-rhyming. They are simply cases of similar sound words. When the associations between words are according to the written form of the words, they are called orthographic links. Some examples are: night - weigh, there - three.

The last class is called other. This class itself is divided into random and no response. Random ones refer to association that there is no clear connection between words and there is no rationale for the associations. This sub-division contains associations which are purely repeated prompt word and it sometimes includes responses to the prompt word that is misheard by respondent too. When the respondent gives no answer, it is referred to as no response.

\section{Word Association Test}

Psycholinguists believe that the mental lexicon is a mental space to store vocabulary. To gain a real insight into word as- 
sociation, psycholinguists have used Word Association Test (WAT) (pratama, 2013). Istifci (2010) also believes that mental lexicon is one of the fundamental issues examined in the research areas of linguistics, psychology and psycholinguistics.

The Word Association Tests are popular means in research which have been using to uncover the mental lexicon and word association of individuals. They have different forms such as oral or written ones, thus a number of prompt words (stimuli) are presented as pen and pencil or orally to the subjects who answer with the first word which comes to their mind (response words). The response words display different facts about subjects' private world including their feelings, believes, characters, and thoughts. Psychologists investigate these associations to get useful information about the nature and possibilities of the response words, and the time that they need to answer the stimuli by using WATs (Nielsen \& Ingwersen, 1999).

The results of these tests are considered as clues and details on the organization and development of lexical items in language learners' mind. Being familiar with different types of associations can result in useful information to be used in both language teaching and language learning process. Word association test results have often been analyzed by word class: supra/subordinate classifications (Sokmen, 1993).

\section{Related Studies}

Roux (2013) conducted a study to explore the relationship between lexical development and word association. The study focuses on revisiting a number of related subjects and knowing the way of organization and storage of vocabulary in the mental lexicon - or, more exactly, coming to an understanding of the lexicon acquisition and organization processes and gaining knowledge of word association (WA). The results of the study indicate some general tendencies in this regard, for example, native and foreign speakers have different patterns in the way of connecting the words in the mental lexicon. Nonetheless, it does not mean that the word association of native speakers may be distinguished from one of foreign speakers. The participants of the study were a group of Japanese speakers of English and a group of English native speakers to precisely investigate the claim that research into word association can lead to knowledge on the way in which words are linked in the mental lexicon. The results of the study broadly were indications of the notion that individuals' word association is something unique and each one has his own pattern. Yet, these results does not deny other results that certain tendencies or types of word association (including the syntagmatic paradigmatic shift in L1-L2 comparisons) warrant further research too. Another finding concentrated on the importance of addressing word associations that were produced due to phonological stimuli.

Post (2007) in his study also tried to work through lexical storage, organization, association, and development in second language learners' mental lexicon. Generally, the results of this paper revealed high organization of words in the mental lexicon of native and second language speakers. The environment appears to influence speakers' word association as well.
In addition, Pigott (2006) attempted to examine learners' mental lexicon in order to better understand the relationship between word association and lexical development. He conducted the study by recruiting six pre-intermediate level learners. They were 19 to 24 years old (four males and two females). The test was administered at the end of a one-year full-time English course, in which they were taught sixteen hours a week by Japanese teachers. The subjects that they studied were grammar, composition, dictionary skills, vocabulary, reading, TOEIC4, video, listening, and speaking skills and four hours a week they studied communication, pronunciation and vocabulary sub skills with native teachers. The findings resulted from this study suggested that the words are semantically related in their minds. Encyclopedic knowledge has an undefined effect but more study is needed.

However different studies have been carried out regarding the way in which individuals organize and link L1 and L2 lexicon in the mind, there are some unanswered questions left for further research in future. The focus of the present study then is on a group of Iranian EFL learners' word association.

\section{METHOD OF THE STUDY}

This section deals with the methodology which was used in this study in order to answer the research questions. It covers participants, instruments, and procedure used to conduct the study.

\section{Participants}

Participants were all non-native speakers of English who are learning English as a foreign language in Iran. In all, 50 students were randomly selected ( 22 males and 28 females) from Razi University and an institute named Iranian in Kermanshah, Iran. 15 out of 50 subjects were from Razi University majoring in English language teaching and studying for an MA. They were 23 to 37 years old ( 1 male and 14 female). And 35 remaining participants were intermediate learners from Iranian institute which were 10 to 18 years old ( 21 males and 14 females).

\section{Instruments}

A perfect word association test (it was presented as pen and paper) which contained eight prompt words from different class word such as noun, verb, preposition, and adjective taken from Post's study (2007); a survey as to participants' individual features such as gender, and age were used in order to gather required data.

\section{Procedure}

The participants were first provided with an instruction sheet in order to gain an understanding on the study and the test. They were also received oral instructions in Persian. The word association test was then administered that contained 8 prompt words with blank space in order to present the responses and bio-data. Finally, they were wanted to provide the first word that comes to mind for each prompt word. Therefore, the required data was gathered through the word association test. After collecting the data, to investigate learners' lexical 
organization and word association, descriptive statistics was used. The answers were grouped into different kinds of word association including syntagmatic and paradigmatic relations (meaning-based links), and clang ones (form-based links). As a result, both meaning-based and form-based associations were taken into consideration in the study and two main kinds of meaning-based responses were: paradigmatic responses, and syntagmatic responses. Finally the frequency of learners' responses was calculated and compared and chi-square tests were run to find differences in word associations.

\section{RESULTS AND DISCUSSION}

To analyze the data, the participants' responses were classified into word association types and the frequency of them was calculated by using SPSS software to discover the way in which words are organized in the mental lexicon. The problem with these responses was that the two prompt words City and Train were from noun word class, but they were considered as verb by some subjects.

In the above Table 1, percentage of 15 high level (adult) learners' syntagmatic and paradigmatic responses was presented. It indeed shows total analysis of responses.

Generally speaking, with reference to the above Table 2 that represents the total analysis of lower level students or teenager ones, syntagmatic responses were more than paradigmatic ones. Other than the stimulus word City that prompted $71.4 \%$ of responses paradigmatic, other stimuli prompted more syntagmatic responses.

The above Table 3 shows the frequency of syntagmatic and paradigmatic responses of male and female participants (higher and lower level learners). It clarifies the potential gender differences of students' answers, the probable different responses of adult and teenager learners will be clear as well.

The Table 4 shows that there were significant differences between male and female learners in the use of syntagmatic response $\left(X^{2}=77.40, p<.001\right)$ and paradigmatic response $\left(X^{2}=4.26, p=.039\right)$ because the $p$ values were lower than.05. It means female learners used both of these responses more than male learners did.

This Table 5 shows that there was a significant difference between male and female learners in the use of syntagmatic response $\left(X^{2}=4.64, p=.031\right)$ because the $p$ value was lower than. 05 while there was not a significant difference between male and female learners in the use of paradigmatic response $\left(X^{2}=.42, p=.516\right)$ because the $p$ value was greater.05. This means male learners used syntagmatic response more than female learners did but there was not a significant difference between male and female learners in the use of paradigmatic response.

The Table 6 indicates that the differences between adult learners and teenager learners' responses were not significant for propmt1 $\left(X^{2}=1.22, p=.544\right)$, propmt $2\left(X^{2}=.45, p=.799\right)$, prompt3 $\left(X^{2}=.00, p=1.000\right)$, prompt4 $\left(X^{2}=5.40, p=.067\right)$, prompt5 $\left(X^{2}=4.40, p=.111\right)$, prompt7 $\left(X^{2}=1.52, p=.217\right)$, and prompt8 $\left(X^{2}=1.81, p=.404\right)$ because all $p$ values were greater than.05. Nevertheless, the difference between adult learners and teenager learners' responses for prompt6 $\left(X^{2}=6.05, p\right.$ $=.048$ ) was significant because the $p$ value was lower than.05.
Table 1. Syntagmatic and paradigmatic responses by percentage_higher level students (Adult learners)

\begin{tabular}{lccc}
\hline Prompt word & Syntagmatic & Paradigmatic & Missing \\
\hline in & $80.0 \%$ & $6.7 \%$ & $13.3 \%$ \\
play & $93.3 \%$ & $00.0 \%$ & $6.7 \%$ \\
study & $93.3 \%$ & $00.0 \%$ & $6.7 \%$ \\
city & $33.3 \%$ & $66.7 \%$ & $00.0 \%$ \\
train & $33.3 \%$ & $40.0 \%$ & $26.7 \%$ \\
to & $86.7 \%$ & $6.7 \%$ & $6.7 \%$ \\
funny & $100.0 \%$ & $00.0 \%$ & $00.0 \%$ \\
big & $73.3 \%$ & $6.7 \%$ & $20.0 \%$ \\
\hline
\end{tabular}

Table 2. Frequency of syntagmatic and paradigmatic responses_lower level learners (Teenager learners)

\begin{tabular}{lccc}
\hline Prompt word & Syntagmatic & Paradigmatic & Missing \\
\hline in & 23 & 6 & 6 \\
play & 32 & 1 & 2 \\
study & 33 & - & 2 \\
city & 4 & 25 & 6 \\
train & 13 & 5 & 17 \\
to & 23 & - & 12 \\
funny & 29 & - & 6 \\
big & 31 & 1 & 3 \\
\hline
\end{tabular}

Table 3. Frequency table_differences between male and female learners' responses

\begin{tabular}{lccll}
\hline Responses & Male & Female & Level & Age range \\
\hline Syntagmatic & 112 & 82 & Lower & Teenager \\
Paradigmatic & 21 & 17 & Lower & Teenager \\
Syntagmatic & 3 & 86 & Higher & Adult \\
Paradigmatic & 5 & 14 & Higher & Adult \\
\hline
\end{tabular}

Table 4. Higher level learners' responses based on gender

\begin{tabular}{lcc}
\hline & Syntagmatic & Paradigmatic \\
\hline Chi-square & $77.404^{\mathrm{a}}$ & $4.263^{\mathrm{b}}$ \\
df & 1 & 1 \\
Asymp. sig. & 0.000 & 0.039 \\
\hline
\end{tabular}

a. 0 cells $(0.0 \%)$ have expected frequencies less than 5 . The minimum expected cell frequency is 44.5 . b. 0 cells $(0.0 \%)$ have expected frequencies less than 5 . The minimum expected cell frequency is 9.5 .

Table 5. Lower level learners' responses based on gender

\begin{tabular}{lcc}
\hline & Syntagmatic & Paradigmatic \\
\hline Chi-square & $4.639^{\mathrm{a}}$ & $0.421^{\mathrm{b}}$ \\
df & 1 & 1 \\
Asymp. sig. & 0.031 & 0.516 \\
\hline
\end{tabular}

a. 0 cells $(0.0 \%)$ have expected frequencies less than 5 . The minimum expected cell frequency is 97.0 . b. 0 cells $(0.0 \%)$ have expected frequencies less than 5 . The minimum expected cell frequency is 19.0 . 


\section{Discussion}

Post (2007), Brown (2006), and Piggot (2006) all reached the claim that words are more semantically organized in the mental lexicon, the results of this study also support semantically related organization of words. The results actually show that meaning-based links are the most important links in L2 learners' mental lexicon and there is no phonological response. Besides this study took the age and gender differences of word associations into consideration. The three last tables reveal the differences in word associations considering age and gender.

Though responses were grouped into four categories namely syntagmatic, paradigmatic, clang, and others (missing), no clang responses exist, apart from missing answers; responses were mainly syntagmatic and paradigmatic, in other words, syntagmatic and paradigmatic links were made with stimulus words. Out of 50 participants, no one made clang or phonological associations. It implies that all the respondents' relations were meaning-based not form-based. According to Table 1, the results are spread as follows. For the first prompt word IN, syntagmatic: $80.0 \%$; paradigmatic: 6.7\%; and missing: $13.3 \%$. For PLAY, syntagmatic: $93.3 \%$, paradigmatic: $00.0 \%$, and missing: $6.7 \%$. Syntagmatic, paradigmatic, and missing for STUDY are respectively: 93.3\%;
$00.0 \%$; 6.7\%. For CITY, we have that, syntagmatic: $33.3 \%$; paradigmatic: $66.7 \%$; missing: $00.0 \%$. Regarding Train, the percentage of syntagmatic is $33.3 \%$; paradigmatic: $40.0 \%$; and missing: $26.7 \%$. Stimulus words TO, FUNNY, and BIG prompted $86.7 \%, 6.7 \%, 6.7 \% ; 100.0 \%, 00.0 \%, 00.0 \%$; $73.3 \%, 6.7 \%, 20.0 \%$ syntagmatic, paradigmatic, and missing respectively.

Table 2 obviously shows the frequency of lower level learners' responses. Accordingly, syntagmatic responses to the prompt word IN were 23 and paradigmatic ones were 6 . Stimulus words PLAY, STUDY, and CITY prompted 32, 33, and 4 syntagmatic responses; and 1, 0, and 25 paradigmatic responses respectively. The stimulus word TRAIN prompted 13 syntagmatic answers and 25 paradigmatic ones. Syntagmatic and paradigmatic responses to TO, FUNNY, and BIG were 23,29 , and $31 ; 0,0,1$ respectively.

\section{CONCLUSION}

This section deals with results from the WAT regarding the way in which EFL learners organize vocabulary and how they make link among the words in their mind. As well as, the potential differences in learners' word association regarding age and gender will be clear.

Table 6. Comparing the students' responses based on age

\begin{tabular}{|c|c|c|c|c|}
\hline Prompts & & Value & $d f$ & Asymp. Sig. (2-sided) \\
\hline \multirow[t]{3}{*}{ Prompt 1} & Pearson chi-square & 1.224 & 2 & 0.542 \\
\hline & Likelihood ratio & 1.344 & 2 & 0.511 \\
\hline & Linear-by-linear association & 0.593 & 1 & 0.441 \\
\hline \multirow[t]{3}{*}{ Prompt 2} & Pearson chi-square & 0.449 & 2 & 0.799 \\
\hline & Likelihood ratio & 0.733 & 2 & 0.693 \\
\hline & Linear-by-linear association & 0.004 & 1 & 0.950 \\
\hline \multirow[t]{4}{*}{ Prompt 3} & Pearson chi-square & 0.017 & 1 & 0.897 \\
\hline & Continuity correction & 0.000 & 1 & 1.000 \\
\hline & Likelihood ratio & 0.017 & 1 & 0.898 \\
\hline & Linear-by-linear association & 0.017 & 1 & 0.898 \\
\hline \multirow[t]{3}{*}{ Prompt 4} & Pearson chi-square & 5.404 & 2 & 0.067 \\
\hline & Likelihood ratio & 6.842 & 2 & 0.033 \\
\hline & Linear-by-linear association & 5.293 & 1 & 0.021 \\
\hline \multirow[t]{3}{*}{ Prompt 5} & Pearson chi-square & 4.398 & 2 & 0.111 \\
\hline & Likelihood ratio & 4.208 & 2 & 0.122 \\
\hline & Linear-by-linear association & 0.434 & 1 & 0.510 \\
\hline \multirow[t]{3}{*}{ Prompt 6} & Pearson chi-square & 6.054 & 2 & 0.048 \\
\hline & Likelihood ratio & 6.944 & 2 & 0.031 \\
\hline & Linear-by-linear association & 3.159 & 1 & 0.075 \\
\hline \multirow[t]{4}{*}{ Prompt 7} & Pearson chi-square & 2.922 & 1 & 0.087 \\
\hline & Continuity correction & 1.524 & 1 & 0.217 \\
\hline & Likelihood ratio & 4.622 & 1 & 0.032 \\
\hline & Linear-by-linear association & 2.864 & 1 & 0.091 \\
\hline \multirow[t]{3}{*}{ Prompt 8} & Pearson chi-square & 1.814 & 2 & 0.404 \\
\hline & Likelihood ratio & 1.693 & 2 & 0.429 \\
\hline & Linear-by-linear association & 1.657 & 1 & 0.198 \\
\hline
\end{tabular}


With reference to leaners' responses to the prompt words of WAT, it can be stated that generally speaking, word association tests are useful psycholinguistic means by which researchers can gain important facts on word association of L2 learners; as syntagmatic and paradigmatic responses were more used by learners participated in the present study, it appears that WAT is an evidence of meaning-based associations (semantic links) within the L2 mental lexicon. Generally, four categories of word association namely syntagmatic, paradigmatic, clang, and other responses were taken into consideration but regarding the students' answers to the stimuli, it should be noted that there was no clang responses or formbased links. Apart from two main categories syntagmatic or paradigmatic association, there were some responses called other or missing classification. It refers to the prompt words that have been left blank (no response) or those responses that had no clear connection with prompt words. All in all, considering adult and teenager participants, it seems that no significant distinction can be made. On the other hand, male and female learners have different patterns in word association in the way that higher level female learners made both syntagmatic and paradigmatic links while higher level male ones used just paradigmatic responses and lower level male learners made syntagmatic connections more than lower level female learners did but as there was just one male learner out of 15 adult ones, it warrants further study in order to test this claim.

\section{PEDAGOGICAL IMPLICATIONS}

Two important types of word association, namely; syntagmatic and paradigmatic links were represented in the learners' answers which have obvious implications for both teaching and learning vocabulary in EFL classroom. According to the findings of the study, it can be suggested that the way in which learners organize and link the words in the mental lexicon is a highly organized way. Therefore, the way of teaching should also be organized. For example, in order to highly organize vocabulary; students need to know about other related knowledge of words such as spelling, pronunciation, and associations made between words. This study suggests students to write down new words and all the information about them such as pronunciation, association, part of speech, meaning, and so on; the way that they can make stronger links which help them remember the new vocabulary. As a result, both EFL teachers and learners should have enough knowledge considering word association.

\section{REFERENCES}

Aitchison, J. (2012). Words in the mind: An introduction to the mental lexicon (4 ${ }^{\text {th }}$ Ed.). Oxford, UK: Blackwell.

Brown, P.S. (2006). A small-scale exploration into the relationship between word-association and learners' lexical development (Master's thesis). Retrieved form http:/ www.birmingham.ac.uk/Documents/college- artslaw/cels
Cremer, M., Dingshoff, D., Beer, M.D., \& Shoonen, R. (2010). Do word associations assess word knowledge? A comparison of L1 and L2, child and adult word association. International Journal of Bilingualism, 20(10), $1-18$.

Fidayanti, F. (2013). Lexical storage in tourism students of vocational educational program: Word association test case study. Abstract retrieved from https://media.neliti. com/media/publications/189784-EN.

Istifci, I. (2010). Playing with words: A study on word association responses. The Journal of International Social Research, 3(10), 360-368.

Moeller, A.K., \& Catalano, T. (2015). Foreign language teaching and learning. International Encyclopedia for Social and Behavioral Sciences, 9, 327-332.

Nielsen, M.L., \& Ingwersen, P. (1999). The word association methodology - a gate way to work-task based retrieval. Paper presented at Final Mira Conference retrieved from https://ewic.bcs.org/content/ConWebDoc/4269, 17-27.

Pigott, J. (2006). The relationship between Word-association and learners' lexical development. Retrieved from https://www.birmingham.ac.uk/Documents/college- artslaw/cels/essays/lexis/LexisThe Relationship betweenWord- association and Learners Lexical DevelopmentJulianPigott.pdf, 1-24.

Post, M. (2007). Word association responses, lexical development and the relationship within the mental lexicon of second language learners (Master's thesis). Retrieved form https://pdfs.semanticscholar.org/f73d/ c174b04e50ffa762fb1b5b924bdd71d56558.pdf

Pratama, A. (2013). Comparing mental lexicon between L1 and L2 on intermediate EFL learners of fourth semester students at study program of English. Abstract retrieved from https://media.neliti.com/media/publications/189816-EN-none.pdf.

Richards, c., \& Schmidt, R. (2002). Dictionary of language teaching and applied linguistics ( $3^{\text {rd }}$ Ed.). London: Longman.

Roux, P.W. (2013). Words in the mind: Exploring the relationship between word association and lexical development. Polyglossia, 24(8), 80-91.

Schmitt, N. (2000). Vocabulary in language teaching. Cambridge: Cambridge University Press.

Schmitt, N. (2014). Size and depth of vocabulary knowledge: What the research shows. Language Learning, a Journal of Research in Language Studies, 64(4), 913-951.

Sokmen, A.J. (1993). Word association results: A window to the lexicons of ESL students. JALT Journal, 15(2), 135-150.

Thomas, D. (2006). Second language word association: How Japanese make mental links between English words they have learned. 1-37.

Udaya, M. (2015). Learning of English vocabulary at the primary level: A study of English readers. IOSR Journal of Humanities and Social Science, 20(10), 43-47. 